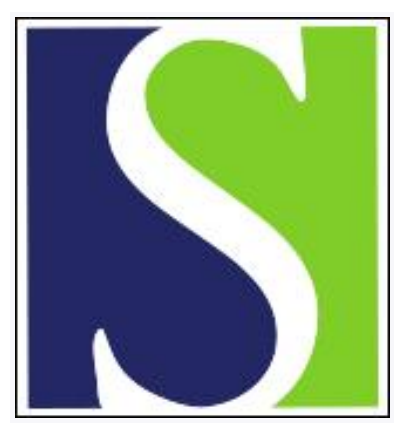

Scand J Work Environ Health 1987;13(3):218-220

https://doi.org/10.5271/sjweh.2060

Issue date: Jun 1987

Lead level of whole blood and plasma in workers exposed to lead stearate.

by Cavalleri A, Minoia C

This article in PubMed: www.ncbi.nlm.nih.gov/pubmed/3616550

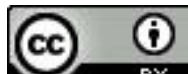




\title{
Lead level of whole blood and plasma in workers exposed to lead stearate
}

\author{
by Alessandro Cavalleri, MD, ${ }^{1}$ Claudio Minoia ${ }^{2}$
}

\begin{abstract}
CAVALLERI A, MINOIA C. Lead level of whole blood and plasma in workers exposed to lead stearate. Scand J Work Environ Health 13 (1987) 218-220. In a group of 23 male workers exposed to lead stearate the levels of lead in whole blood and plasma were determined and compared to those obtained from a group of 23 subjects exposed to inorganic lead compounds. The mean values for lead in whole blood were similar in both groups, while the mean lead concentration in plasma was 0.1729 (SD 0.0677) $\mu \mathrm{mol} / 1$ for those exposed to lead stearate and 0.0936 (SD 0.0577) $\mu \mathrm{mol} / 1$ for those exposed to other lead compounds. The difference was highly significant. The percentage ratio for lead in plasma to lead in whole blood, which can be considered a "bioavailability index" for lead, proved to be two times higher for stearate workers than for subjects exposed to inorganic lead compounds. The data suggest that the different chemical properties of absorbed lead stearate may cause a different distribution of the metal in different blood compartments, the plasma compartment having a higher affinity for lead stearate than for other lead compounds. Because the plasma fraction has a greater bioavailability, lead stearate could induce toxic effects that differ (possibly being severer) from those caused by other lead compounds at similar absorbed doses.
\end{abstract}

Key terms: bioavailability of lead, lead in blood, lead in plasma.

The biological monitoring of subjects exposed to inorganic lead is usually performed by measuring the level of lead in whole blood $(\mathrm{PbB})$. This measure is generally considered to be a good estimate of current exposure and to show a close relationship to the commonly adopted indicators of biological effects. Furthermore, it is assumed that the PbB level is always a reliable indicator of the biologically active lead responsible for the toxic effects at any given period of time (4).

Under the same conditions of absorbed dose, occupational and environmental exposure to different inorganic lead compounds is implicitly considered equivalent and hence monitored by the usual indices of uptake and biological effects on the assumption that each compound is provided with identical toxicokinetic and toxicodynamic properties.

During an examination of a group of workers exposed to lead stearate, we occasionally noted a poor relationship between the concentration of lead in blood and the level of free erythroporphyrin in red blood cells. This deviation from the expected values prompted us to study the distribution of lead in the blood compartments of workers exposed to lead stearate in com-

\footnotetext{
1 Cattedra di Medicina del Lavoro, University of Modena, Modena, Italy.

2 Centro di Fisiopatologia e Sicurezza del Lavoro, Fondazione Clinica del Lavoro, University of Pavia, Pavia, Italy.
}

Reprint requests to: Professor A Cavalleri, Cattedra di Medicina del Lavoro, University of Modena, Via Campi 287, 41100 Modena, Italy. parison to that in the blood compartments of subjects exposed to other inorganic lead compounds.

\section{Subjects and methods}

The study was performed on 23 male workers of a plastics factory producing polyvinyl chloride pipes. The subjects were exposed to high levels of lead (the environmental airborne lead ranged from 140 to 300 $\mu \mathrm{g} / \mathrm{m}^{3}$ ), and their $\mathrm{PbB}$ varied from 1.59 to $5.07 \mu \mathrm{mol} / \mathrm{l}$. A group of 23 male workers of the same age with high levels of $\mathrm{PbB}$ (range $2.08-8.45 \mu \mathrm{mol} / \mathrm{l}$ ) and exposed to inorganic lead compounds in storage battery production and the ceramic industry was chosen for comparison.

The $\mathrm{PbB}$ level was measured by the standard extraction-chelation procedure reported by Volosin and coworkers (7) and the plasma lead ( $\mathrm{PbP}$ ) level was determined by the method previously described by us (2) using heparin as an anticoagulant. The latter technique has a sensitivity of $0.0048 \mu \mathrm{mol} / \mathrm{l}$, an accuracy ranging between 88.7 and $93.7 \%$ (recovery at the plasma lead level of 0.0241 and $0.1448 \mu \mathrm{mol} / 1$, respectively) and a within-run precision of 1.7-5.0\% (coefficient of variation at the level of 0.0724 and $0.0144 \mu \mathrm{mol} / \mathrm{l}$, respectively).

The packed red-cell volume in both groups was also measured.

\section{Results}

The mean level of $\mathrm{PbB}$ in the 23 workers exposed to lead stearate was 3.47 (SD 0.84) $\mu \mathrm{mol} / \mathrm{l}$, whereas for 
the reference group a mean value of 3.91 (SD 1.65) $\mu \mathrm{mol} / \mathrm{l}$ was determined. On the contrary the mean $\mathrm{PbP}$ concentration in the group exposed to lead stearate was much higher $[0.1729$ (SD 0.0677) $\mu \mathrm{mol} / \mathrm{l}]$ than the mean level determined for the reference group [0.0936 (SD 0.0577) $\mu \mathrm{mol} / \mathrm{l}]$ with a highly significant difference $(P<0.0001)$. A similar significant difference was found when the results were expressed as the ratio $\mathrm{PbP}: \mathrm{PbB} \times$ 100 , which measures the percentage fraction of lead which is more bioavailable in plasma. This value was found to be 5.3 (SD 2.6) \% in lead stearate workers and 2.5 (SD 1.4) \% in the reference group.

The individual data are summarized in figure 1 . In order to rule out a possible difference in the number of red blood cells between the groups, the volume of packed red cells was determined. A mean value of 47.1 (SD 3.3) $\mathrm{ml} / \mathrm{dl}$ was obtained for those exposed to lead stearate and a corresponding value of 46.8 (SD 4.5) $\mathrm{ml} / \mathrm{dl}$ for those exposed to other lead compounds.

\section{Discussion}

The biological meaning and toxicological importance of the lead content in different blood compartments are not the same. Therefore the plasma fraction should not be overlooked in the evaluation of the kinetics of the metal in the body, its distribution in tissues, excretion mechanisms and rates, and the potential toxic effects. The plasma pool is more related than the erythrocyte pool to the diffusibility of lead outside the blood stream and to biological membrane permeability. Infants' plasma lead levels are better correlated to maternal plasma values than are fetal-maternal concentrations of red blood cells (3). A significant relationship has been demonstrated between $\mathrm{PbP}$ and cerebrospinal fluid lead but not between $\mathrm{PbB}$ and cerebrospinal fluid lead levels (1).

Since the $\mathrm{PbP}$ fraction has a greater bioavailability than the lead pool of the red blood cells and the $\mathrm{PbP}$ is in equilibrium with extravascular compartments, the lead content of plasma should be considered a better estimate of the internal lead dose than the level of the metal in whole blood. In workers exposed to lead stearate, the plasma values were actually twice the level found in those exposed to other lead compounds bearing a comparable level of lead in whole blood. The ratio $\mathrm{PbP}: \mathrm{PbB} \times 100$, which can be called a "bioavailability index," was equal to $5.3 \%$ in the former group and $2.5 \%$ in the latter.

These data suggest that the different chemical properties of lead stearate may induce a different distribution of the metal in different blood compartments, the partition coefficient plasma : erythrocytes shifting toward the plasma compartment. This peculiar distribution, which occurs when lead is introduced into an organic molecular structure, could bring about different, or possibly severer, toxic effects than those caused by other lead compounds at a similar absorbed

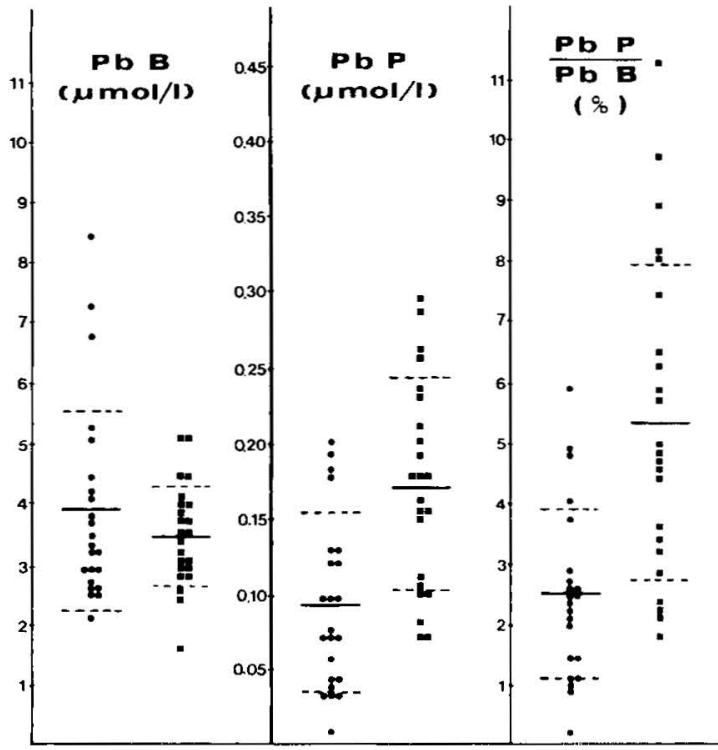

Figure 1. Individual values of lead in whole blood $(\mathrm{PbB})$, of lead in plasma $(\mathrm{PbP})$, and of the ratio $\mathrm{PbB}: \mathrm{PbP} \times 100$ for 23 workers exposed to inorganic lead compounds $(O)$ and 23 workers

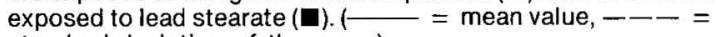
standard deviation of the mean).

dose. The possibility arises since, in exposure to lead stearate, a larger fraction of absorbed lead is available to diffuse in extravascular tissues, and subsequently the dose which comes into direct contact with various tissue cells could be increased.

In addition liver damage, usually not evident in connection with exposure to other lead compounds, has been reported for experimental animals (6) and for humans exposed to lead stearate (5).

The possibility that dissimilar effects are caused by different lead compounds should therefore be taken into consideration and investigated. The usefulness of measuring the $\mathrm{PbP}$ level in biological monitoring should also be considered. Due to its greater bioavailability, the plasma fraction is likely to influence the lead concentrations in other compartments directly. Therefore its determination could provide different and more specific information of the lead fraction transferable to soft tissues than that derived from lead in whole blood.

\section{References}

1. Cavalleri A, Minoia C, Ceroni M, Poloni M. Lead in cerebrospinal fluid and its relationship to plasma lead in humans. J Appl Toxicol 4 (1984) 63-65.

2. Cavalleri A, Minoia C, Pozzoli L, Baruffini A. Determination of plasma lead levels in normal subjects and in lead exposed workers. Br J Ind Med 35 (1978) 21-26.

3. Cavalleri A, Minoia C, Pozzoli L, Polatti F, Bolis PF. Lead in red blood cells and in plasma of pregnant women and their offspring. Environ Res 17 (1978) 403-408.

4. Hernberg S. Biochemical and clinical effects and responses as indicated by blood concentration. In: Singhal RL, 
Thomas JA. Lead toxicity. Urban \& Schwarzenberg, Baltimore-Munich 1980, pp 367-399.

5. Sassi C, Finulli M, Nava C. Il saturnismo nella lavorazione dello stearato di piombo. Med Lav 52 (1961) 658-666.

6. Schmidt P, Gohlke R, Naumann NJ. Tierexperimentelle Untersuchungen zur Toxicität der Bleistearate. Int Arch Arbeitsmed 26 (1970) 117-144.
7. Volosin MT, Kubasik NT, Sine HE. Use of the carbon rod for analysis of lead in blood: Three methods compared. Clin Chem 21 (1975) 1986-1987.

Received for publication: 13 February 1987 